\title{
PENGUNGKAPAN INFORMASI HUMAN CAPITAL DAN HARGA SAHAM STUDI PADA HIGH INTELLECTUAL CAPITAL (IC) INTENSIVE INDUSTRIES DI BURSA EFEK INDONESIA
}

\author{
Andreas Sugianto W \\ e-mail: andreas.sugianto94@gmail.com \\ Felizia Arni Rudiawarni \\ e-mail: felizia@staff.ubaya.ac.id \\ Fakultas Bisnis dan Ekonomika, Universitas Surabaya
}

\begin{abstract}
The accounting overview on human capital considerate as intellectual capital (IC) in a group of intangible assets. Human capital began to be recognized as a key factor of a competitive advantage. Disclosures information related to human capital contribute to the reduction of asymmetric information between firms and their investors. This study aims to describe the aims of study are to describe the relationship between human capital information disclosure and stock price. The object of this study are firms that have in the high Intellectual Capital (IC) intensive industry that which disclosing information about their human capital. This study finds that the finding of research convince that disclosure of human capital has positive effect on stock prices, particularly the disclosure of information regarding the qualifications and competence of human capital. In other words, in the context of information about, human capital is value relevant.
\end{abstract}

Keywords: human capital disclosure; relevant value; intellectual capital; share price

\section{PENDAHULUAN}

Menyambut MEA (Masyarakat Ekonomi ASEAN) yang bergulir tahun 2015, secara perlahan pasar bebas ASEAN mulai berlangsung. Dari segi jumlah, penduduk Indonesia adalah terbesar di ASEAN dibandingkan negara lainnya. Disisi lain, kualitas dari penduduk Indonesia belum sebanding dengan jumlah penduduknya. Menurut Human Capital Report 2015 yang dirilis World Economic Forum (WEF), Human Capital Index Indonesia hanya berada di angka 3,03 dari indeks maksimal sembilan. Dalam dunia akuntansi, Edvinsson dan Malone (1997) menyatakan human capital sebagai aset tidak berwujud (intangible) penting dalam sebuah organisasi bisnis. Bahkan secara spesifik, human capital adalah sumber yang sangat berharga dan merupakan faktor kunci keunggulan dari sebuah persaingan (Gunther et al., 2003).

Fakta di Indonesia menunjukkan bahwa regulasi untuk perseroan terbatas (PT) yaitu UU No. 40 Tahun 2007, Bagian IV, Pasal 66 mengenai laporan tahunan perusahaan terbuka tidak mengisyaratkan PT untuk wajib mengungkapkan informasi terkait human capital. Jika tergolong sebagai pengungkapan sukarela maka informasi mengenai human capital akan berpotensi besar tidak akan diungkapkan. Akibatnya, investor dan banyak pemangku kepentingan lain tidak dapat memastikan potensi dari faktor human capital perusahaan yang memberikan nilai tambah tersendiri.

Sejak 1990, human capital mulai diperhatikan perusahaan sehingga terlihat dari mulai diungkapkannya informasi human capital secara khusus (PricewaterhouseCoopers, 2014). Firer dan Williams (2003) telah meneliti 75 perusahaan yang listing di Afrika Selatan dan tergolong kedalam high Intellectual Capital (IC) intensive sectors. Hasilnya, investor dan pasar lebih memperhatikan informasi mengenai aset-aset fisik yang nyata dibandingkan IC asset (termasuk didalamnya human capital). Penelitian Lev dan Zarowin (1999) di Amerika juga menemukan penurunan relevansi nilai dari pengungkapan informasi aset tidak berwujud perusahaan selama 20 tahun dan 40 tahun dalam data pasar di US.

Tetapi, Gamerschlag (2013) melakukan penelitian yang menyatakan informasi mengenai human capital memiliki relevansi nilai terhadap 
harga saham. Selanjutnya Lijili dan Zeghal (2006) melakukan penelitian mengenai pengungkapan informasi human capital di Amerika Serikat. Hasilnya terdapat hubungan positif antara pengungkapan informasi performa dan efisiensi human capital dengan harga sahamnya.

Minimnya penelitian mengenai human capital di Indonesia dan berdasarkan uraian dari research gap yang ada, maka studi ini berusaha meneliti mengenai pengungkapan informasi human capital terkait relevansinya terhadap harga saham di Indonesia. Terkait dengan intellectual capital (IC), terdapat beberapa industri yang dianggap memiliki ketergantungan lebih terhadap IC yang kemudian disebut sebagai industri high IC intensive. Pengungkapan informasi antar bagian intellectual capital (structural, external, dan human capital) memiliki proporsi sama dalam sektor perusahaan high IC intensive (Petty dan Riccery, 2006). Studi ini meneliti perusahaan-perusahaan yang terdaftar di Bursa Efek Indonesia dan tergolong dalam industri yang high IC intensive berdasarkan kategori Firer dan Williams (2003), yaitu banking and finance, technology, dan services.

Artikel ini disajikan dalam beberapa bagian. Bagian kedua berisikan pengembangan hipotesis. Bagian ketiga menyajikan metode penelitian. Bagian keempat yaitu pembahasan yang menjelaskan hasil dan analisis penelitian. Bagian terakhir menyajikan kesimpulan dan keterbatasan dari penelitian ini.

\section{TINJAUAN PUSTAKA}

Edvinson dan Malone (1997), dan Ross et al., (2005) menyatakan IC adalah komponen aset tidak berwujud yang berhubungan dengan pengetahuan, keahlian, dan sistem informasi. Stewart (1997) turut memperluas definisi IC yang dinyatakan sebagai gabungan dari intellectual material (knowledge, information, intellectual property, serta experience) yang dapat digunakan guna menciptakan kekayaan dengan mengembangkan sustainable competitive advantage suatu organisasi. Sebelumnya, IC bukanlah aset yang banyak diperhatikan perusahaan karena sulitnya menelusuri manfaat yang dihasilkan secara langsung. Namun sejak 1990 IC bahkan menjadi fokus tersendiri bagi perusahaan (Sullivan, 2000).

Banyak framework untuk mengketegorikan IC kedalam beberapa komponen. Namun, secara garis besar dan sederhana, intellectual capital akan dibagi menjadi dua komponen besar yaitu human capital dan structural capital. Menurut Zeghal dan Maaloul (2010), pengklasifikasian ini merupakan pengklasifikasian yang paling banyak digunakan sebagai literatur intellectual capital sampai saat ini.

Penelitian ini berfokus pada bagian human capital yang dimiliki dan diungkapkan oleh badan usaha. Menurut Barro (2001), dari beberapa komponen intellectual capital yang ada dalam berbagai model, human capital merupakan faktor utama pertumbuhan ekonomi dan kunci sukses memenangkan persaingan bisnis.

Sama seperti intellectual capital (IC), terdapat banyak versi komponen dari human capital berdasarkan para ahli. Penelitian ini menggunakan kerangka human capital yang dikemukakan oleh Gamerschlag (2013 karena pembagian komponen human capital yang disajikan lebih detail dibandingkan kerangka lainnya.

Gamerschlag (2013) membagi human capital ke dalam tiga kategori besar yaitu qualification (competence), motivation (commitment), dan personnel. Secara detail terbagi atas 27 kata kunci (secara lengkap dapat dilihat pada LAMPIRAN) yang mengindikasikan pembagian dari kategori human capital information perusahaan melalui laporan tahunannya.

Qualification (competence) dalam hal ini mencakup banyak informasi seperti kompetensi, pendidikan, keahlian, pengetahuan, pembelajaran, kualifikasi, spesialisasi, dan pelatihan. Komponen kedua human capital adalah motivation (commitment). Menurut Gamerschlag (2013) komponen ini membicarakan hubungan baik yang terjalin antara para pekerja dengan perusahaan. Komponen terakhir dari human capital dari kerangka ini yaitu personnel. Informasi ini mencerminkan bagaimana sumber daya manusia dari suatu badan usaha berawal. Program perekrutan karyawan, keberagaman yang ada dalam badan usaha, dan program-program pemberdayaan SDM badan usaha.

Pengungkapan informasi human capital di Indonesia bukanlah termasuk pengungkapan yang bersifat mandatory (diwajibkan). Berarti, setiap badan usaha memiliki kebebasan untuk mengungkapkan informasi human capital (sukarela). Hal ini terbukti dari tidak tercantumnya kewajiban pengungkapan human capital dalam UU No. 40 Tahun 2007, Bagian IV, Pasal 66 mengenai laporan tahunan perseroan terbatas.

Penelitian ini menggunakan content analysis dalam menjelaskan pengukuran dan pelaporan terhadap human capital dalam laporan tahunan (annual report). Lebih tepatnya penelitian ini menggunakan disclosure index. 


\section{Hubungan antara Human Capital Disclosure dengan Harga Saham}

Informasi dinilai relevan adalah ketika informasi tersebut dapat mempengaruhi proses dari pengambilan putusan ekonomi pengguna dengan membantu mengevaluasi peristiwa masa lalu, masa kini, masa depan, menegaskan, atau mengoreksi hasil evaluasi pengguna di masa lalu (SAK, 2015). Penelitian dirancang untuk menerapkan nilai-nilai akuntansi terhadap penilaian ekuitas perusahaan. Relevansi nilai tercermin dalam bentuk pelaporan informasi akuntansi yang memiliki model prediksi berkaitan dengan nilai pasar sekuritas.

Pengungkapan human capital memiliki peran penting dalam mengurangi asimetri informasi antara pemegang saham dan manajemen, sehingga dapat dijadikan bahan pertimbagan lebih bagi investor dalam mengevaluasi sebuah badan usaha. Kurangnya pengungkapan informasi penting akan menyebabkan para investor tidak dapat mengetahui value adding potential yang ada dalam sebuah badan usaha (Lev dan Zarowin, 1999). Dalam keadaan pasar modal yang efisien, harga saham sebuah perusahaan selalu merefleksikan seluruh informasi publik yang ada (Scott, 2015). Pengungkapan informasi yang bernilai tambah bagi investor dalam keputusannya membeli atau menjual saham (Abhayawansa dan Guthrie, 2012; Wyatt, 2008).

Teori diatas dibuktikan oleh Gamerschlag (2013) yang menyelidiki adanya hubungan antara informasi human capital dengan harga saham. Penelitian oleh Gamerschlag (2013) sejalan dengan para peneliti terdahulu yang menyatakan pentingnya pengungkapan informasi intellectual capital (termasuk didalamnya human capital) sehingga memiliki relevansi nilai (Wyatt, 2008; Abdolmohammadi, 2005; Uyar dan Kilic, 2012).

Oleh sebab itu, hipotesis yang hendak diteliti dalam studi ini adalah:

$\mathrm{H}_{1}$ : pengungkapan informasi human capital berpengaruh positif terhadap harga saham perusahaan high IC intensive industries yang terdaftar di BEI periode 2012-2014.

\section{METODE PENELITIAN}

Penelitian ini mengambil obyek perusahaan publik di Bursa Efek Indonesia (BEI) yang mengungkapkan informasi human capital dalam laporan tahunannya dan tergolong dalam industri High IC Intensive berdasarkan klasifikasi dari Firer dan Williams (2003). Laporan tahunan yang digunakan mulai 2012 hingga 2014. Data dalam penelitian ini diperoleh melalui media internet, diantaranya adalah database BEI yang diakses melalui website IDX dan Yahoo Finance.

Pada Tabel 1 nampak jumlah badan usaha yang termasuk dalam sektor High IC Intensive industries dalam pengamatan selama tiga tahun yaitu 2012, 2013, dan 2014 adalah sebanyak 247 tahun perusahaan. Dari jumlah ini kemudian diseleksi dengan kriteria utama yaitu terdapat paling sedikit satu pengungkapan kata kunci mengenai infomasi human capital (brain power, competence, competencies, education, expertise, intangible skills, intelligence, know-how, knowledge, learning, qualification, specialist, training, absence, career, employee retention, employee satisfaction, employee turnover, entrepreneurial spirit, motivation, staff turnover, diversity, empowerment, human resource, personnel, recruiting, dan recruitment).

Infornasi mengenai human capital diambil dari laporan tahunan (annual report) digunakan sebagai "informasi lain-lain". Oleh karena itu, ada empat variabel yang harus dikompilasi. Keempat variabel ini menggunakan variabel-variabel yang digunakan oleh Gamerschlag (2013), yaitu total pengungkapan tentang human capital (HCRDISC), jumlah pengungkapan terkait kualifikasi dan kompetensi (HCRQC), jumlah pengungkapan mengenai motivasi dan komitmen (HCRMC), dan jumlah pengungkapan mengenai masalah personnel (HCRPS). Menurut Gamerschlag (2013) terdapat 27 kata kunci yang dirumuskan kedalam informasi human capital, secara lengkap seluruh kata kunci dapat dilihat dalam LAMPIRAN. Semua variabel diambil dari jumlah pengungkapan informasi human capital dalam laporan tahunan (annual report) perusahaan setiap tahun. Kemudian, angka (jumlah pengungkapan) itu dibagi dengan jumlah pengungkapan terbesar sehingga didapatkan angka indeks. Dengan demikian, indeks tersebut mencerminkan tingkat pengungkapan informasi human capital suatu perusahaan dalam setiap kategori berdasarkan Gamerschlag (2013).

Pada Tabel 1 berikut ini ditampilkan kriteria pengambilan sampel sebagai objek penelitian. Dari total 247 tahun perusahaan, dieliminasi sebanyak 27 tahun perusahaan sehingga menjadi 220 tahun perusahaan (firm year) yang akan digunakan sebagai objek penelitian.

\section{Pengujian Hipotesis}

Hipotesis dalam penelitian ini, Pengungkapan informasi human capital berpengaruh signifikan positif dengan harga saham yang dilakukan 
perusahaan high IC intensive industries yang terdaftar di BEI periode 2012-2014. Hipotesis tersebut lebih lanjut diuji dengan analisis regresi berganda. Adapun persamaan yang dirumuskan (Model A):

$$
\begin{gathered}
S P=\beta_{0}+\beta_{1} \times H C R D I S C+\beta_{2} \times E Q P S+ \\
\beta_{3} \times N I S+\varepsilon
\end{gathered}
$$

Kemudian, untuk meneliti lebih dalam mengenai pengaruh dari setiap jenis kategori pengungkapan informasi human capital terhadap harga saham maka peneliti menambahkan persamaan kedua. Persamaan kedua ini juga diuji melalui analisis regresi berganda. Berikut adalah persamaan yang dirumuskan untuk tujuan ini (Model B): $S P=\beta_{0}+\beta_{1} \times H C R Q C+\beta_{2} \times H C R M C+\beta_{3} \times H C R P S+$ kali ini memiliki rentang nilai yang lebar.

$\beta_{4} \times E Q P S+\beta_{5} \times N I S+\varepsilon$

Keterangan:

SP = harga penutupan saham (share price)

EQPS = nilai buku ekuitas (book value of equity)

NIS = laba bersih per lembar saham (net income/share)

HRCDISC $=$ indeks pengungkapan human capital

HCRQC = indeks pengungkapan human capital terkait kualifikasi/kompetensi

HCRMC = indeks pengungkapan human capital terkait motivasi/komitmen

HCRPS = indeks pengungkapan human capital terkait personnel

Statistik deskriptif seluruh variabel dalam penelitian yang disajikan pada Tabel 2. Share price (SP) sebagai variabel dependen dalam penelitian

Tabel 1

Kriteria Pengambilan Sampel untuk Objek Penelitian

\begin{tabular}{lcccc}
\hline \multicolumn{1}{c}{ Keterangan } & $\begin{array}{c}\text { Tahun } \\
2012\end{array}$ & $\begin{array}{c}\text { Tahun } \\
2013\end{array}$ & $\begin{array}{c}\text { Tahun } \\
2014\end{array}$ & $\begin{array}{c}\text { Total Firm } \\
\text { Year }\end{array}$ \\
\hline $\begin{array}{l}\text { Perusahaan yang tergolong high IC intensive } \\
\text { industries }\end{array}$ & 77 & 82 & 88 & 247 \\
\hline $\begin{array}{l}\text { Sampel yang tidak melakukan pengungkapan } \\
\text { kata kunci informasi human capital atau } \\
\text { informasi share price }\end{array}$ & $(7)$ & $(9)$ & $(11)$ & $(27)$ \\
\hline $\begin{array}{l}\text { Total badan usaha yang menjadi objek } \\
\text { penelitian selama tiga periode }\end{array}$ & 70 & 73 & 77 & 220 \\
\hline \begin{tabular}{l} 
Sumber: data diolah \\
\hline
\end{tabular}
\end{tabular}

Variabel HCRQC, HCRMC, dan HCRPS merupakan angka indeks yang berasal dari pembagian jumlah pengungkapan masing-masing variabel dibagi dengan jumlah pengungkapan tertinggi variabel tersebut diantara objek penelitian. Semuanya berkisar antara 0 dan 1 . HCRDISC dalam penelitian ini digunakan sebagai proksi yang mempengaruhi SP, semakin tinggi HCRDISC maka akan mempengaruhi nilai SP menjadi semakin tinggi.

Tabel 2 juga menunjukkan bahwa pengungkapan informasi human capital di Indonesia tergolong rendah. Hal ini terlihat dari nilai rata-rata (mean) pengungkapan informasi human capital yang berada di angka 0,22 diantara nilai 0 (nol) dan 1 (satu). Padahal, sektor badan usaha yang digunakan sebagai objek penelitian merupakan high IC intensive industries yang seharusnya memiliki pengungkapan informasi mengenai intellectual capital (termasuk didalamnya human capital) relatif lebih tinggi dibandingkan sektor-sektor lain. Hal ini disebabkan pengungkapan informasi human capital masih berada dalam level voluntary disclosure ditambah belum adanya kesadaran mengenai pengungkapan informasi ini sehingga tingkat pengungkapannya masih rendah.

Tabel 3 menyajikan korelasi antar variabel. Secara umum, seluruh variabel dependen yaitu HCRDISC, HCRQC, HCRMC, HCRPS, NIS, dan EQPS berkorelasi positif dengan harga saham. Kemudian, dari hasil pengujian diatas juga menunjukkan bahwa hubungan antara total pengungkapan informasi human capital (HCRDISC) dan pengungkapan terkait informasi kualifikasi-kompetensi (HCRQC) terhadap harga saham sebagai variabel dependen masih bersifat terbatas. Hubungan yang terbatas ini terlihat dari tingkat keeratan hubungan antar variabel yang secara umum menunjukkan hubungan yang lemah. Pengungkapan informasi mengenai motivasikomitmen (HCRMC) dan terkait personnel 
(HCRPS) bahkan lebih lemah lagi pengaruhnya terhadap harga saham. Sedangkan, informasi laba bersih (NIS) dan nilai buku ekuitas (EQPS) memiliki hubungan korelasi yang kuat terhadap harga saham pada Model A.
Dalam permodelan kedua (B), seluruh variabel independen juga memiliki hubungan positif dengan harga saham sebagai variabel dependen.

Tabel 2

Statistik Deskriptif

\begin{tabular}{lrrrrr}
\hline & N & \multicolumn{1}{c}{ Minimum } & \multicolumn{1}{c}{ Maximum } & \multicolumn{1}{c}{ Mean } & \multicolumn{1}{c}{ Std. Deviation } \\
\hline HCRQC & 220 & 0,00 & 1,00 & 0,2099 & 0,21788 \\
\hline HCRMC & 220 & 0,00 & 1,00 & 0,1138 & 0,15789 \\
\hline HCRPS & 220 & 0,00 & 1,00 & 0,1542 & 0,17168 \\
\hline HCRDISC & 220 & 0,00 & 1,00 & 0,2177 & 0,21694 \\
\hline SP & 220 & 50,00 & 13500,00 & 1561,3932 & $2.462,22089$ \\
\hline NIS & 220 & $-49,36$ & 1707,21 & 138,4154 & 234,03749 \\
\hline EQPS & 220 & 25,04 & 8833,31 & 988,1238 & $1.388,50820$ \\
\hline Valid N (listwise) & 220 & & & & \\
\hline
\end{tabular}

Sumber: data diolah

Tabel 3

Hasil Uji Koefisien Korelasi Model A dan B

\begin{tabular}{|c|c|c|c|c|}
\hline \multicolumn{5}{|c|}{ Panel A: Model A $(\mathrm{N}=220)$} \\
\hline & SP & HCRDISC & NIS & EQPS \\
\hline SP & 1 & $0,350^{* * * *}$ & $0,762^{* * * *}$ & $0,669^{* * * *}$ \\
\hline HCRDISC & $0,350^{* * * *}$ & 1 & $0,337^{* * * *}$ & $0,264^{* * * *}$ \\
\hline NIS & $0,762^{* \cdots *}$ & $0,3377^{* * *}$ & 1 & $0,725^{* \cdots *}$ \\
\hline EQPS & $0,669^{* * *}$ & $0,264^{\text {****** }}$ & $0,725^{* * *}$ & 1 \\
\hline
\end{tabular}

\begin{tabular}{|c|c|c|c|c|c|c|}
\hline \multicolumn{7}{|c|}{ Panel B: Model B $(\mathrm{N}=220)$} \\
\hline & $\mathrm{SP}$ & HCRQC & HCRMC & HCRPS & NIS & EQPS \\
\hline SP & 1 & $0,389^{* * * *}$ & $0,144^{* *}$ & $0,280^{\text {**** }}$ & $0,762^{* * *}$ & $0,669^{* * * *}$ \\
\hline HCRQC & $0,389^{* * * *}$ & 1 & $0,556^{* * *}$ & $0,619^{* * * *}$ & $0,376^{* * * 2}$ & $0,271^{* *}$ \\
\hline HCRMC & $0,144^{* *}$ & $0,556^{* * * *}$ & 1 & $0,509^{* * * * *}$ & $0,131^{* * *}$ & $0,121^{* * *}$ \\
\hline HCRPS & $0,280^{* * * *}$ & $0,619^{* * * *}$ & $0,509^{* * * * *}$ & 1 & $0,283^{* * * *}$ & $0,255^{* * *}$ \\
\hline NIS & $0,762^{* * * * *}$ & 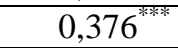 & $0,131^{* * *}$ & $0,283^{\text {***** }}$ & 1 & $0,725^{\text {**** }}$ \\
\hline EQPS & $0,669^{* * * *}$ & $0,271^{* * * *}$ & $0,121^{* * *}$ & $0,255^{\text {**** }}$ & $0,725^{\text {**** }}$ & 1 \\
\hline
\end{tabular}

Sumber: data diolah

\section{PEMBAHASAN}

Hasil pengujian regresi dari permodelan ditunjukkan pada Tabel 4. Dalam model regresi A, variabel independen yang meliputi HCRDISC, NIS, dan EQPS secara silmultan mempengaruhi SP sebagai variabel dependen. Begitu pula dengan model regresi $\mathrm{B}$, variabel independennya yang meliputi HCRQC, HCRMC, HCRPS, NIS, dan EQPS juga berpengaruh secara simultan terhadap SP sebagai variabel dependen.
Variabel independen utama permodelan A yaitu HCRDISC berpengaruh signifikan terhadap variabel dependen SP. Hasil ini menyimpulkan bahwa pengungkapan informasi mengenai human capital berpengaruh terhadap harga saham perusahaan. Sedangkan variabel HCRQC, HCRMC, dan HCRPS yang merupakan variabel independen permodelan B memiliki signifikansi yang berbeda-beda. Variabel kontrol dalam kedua permodelan penelitian ini yaitu NIS dan EQPS juga berpengaruh positif signifikan terhadap SP. 
Tabel 3

Hasil Pengujian

\begin{tabular}{|c|c|c|c|c|}
\hline & \multicolumn{2}{|c|}{ Model A } & \multicolumn{2}{|c|}{ Model B } \\
\hline & Koef. & Nilai t & Koef. & Nilai t \\
\hline Konstanta & 85,140 & 0,551 & 80,980 & 0,518 \\
\hline HCRQC & & & 1613,411 & $2,382 *$ \\
\hline HCRMC & & & $-510,031$ & $-0,621$ \\
\hline HCRPS & & & $-87,956$ & $-0,110$ \\
\hline HCRDISC & 1136,858 & $2,242 *$ & & \\
\hline NIS & 5,815 & $8,831 * *$ & 5,614 & $8,373 * *$ \\
\hline EQPS & 0,429 & $3,960 * *$ & 0,442 & $4,062 * *$ \\
\hline F sig. & & $116,466 * *$ & & $70,495 * *$ \\
\hline Adj $R^{2}$ & & 0,613 & & 0,613 \\
\hline
\end{tabular}

Hasil pengujian hipotesis penelitian menunjukkan bahwa ada pengaruh yang signifikan antara variabel independen utama yaitu HCRDISC terhadap variabel dependen SP. Artinya bahwa pengungkapan informasi mengenai human capital memiliki pengaruh signifikan terhadap harga saham. Hal ini sejalan dengan penelitian Gamershlag (2013) yang menyatakan terdapat hubungan yang sinifikan antara pengungkapan human capital information dan harga saham badan usaha. Hasil penelitian ini juga sesuai dengan hasil penelitian Abdolmohammadi (2005) dan Uyar dan Kilic (2012) yang menyatakan ada hubungan positif antara pengungkapan informasi sukarela terhadap market firm value. Dilain sisi, penelitian ini juga penunjukkan hasil yang berbeda dengan penelitian Lev dan Zarowin (1999) yang menyatakan terjadi penurunan relevansi nilai dari pengungkapan informasi aset tidak berwujud perusahaan selama 20 tahun dalam data pasar di US. Selain itu, penelitian Firer dan Williams (2003) di Afrika juga menyebutkan pengungkapan informasi aset-aset fisik perusahaan relevan terhadap nilai perusahaan dibandingkan pengungkapan informasi intellectual capitalnya (termasuk didalamnya informasi human capital).

Hasil penelitian ini juga menguji bagaimana sub-kelas pengungkapan informasi human capital seperti informasi qualification-competence (QC), motivation-commitment (MC), dan informasi personnel (PS) mempengaruhi harga saham. Ternyata, informasi QC berpengaruh signifikan terdahap harga saham. Tetapi, pengungkapan informasi MC dan PS tidak secara signifikan mempengaruhi harga saham. Hal ini disebabkan, pengungkapan informasi $\mathrm{QC}$ oleh perusahaan dianggap sebagai isu penting aset dalam bentuk sumber daya organisasi (Blaug, 1976) (Spender dan Grant, 1996).
Informasi QC yang terdiri dari (tampilkan 13 kata kunci ini) 13 kata kunci terkait kualifikasi dan kompetensi dari sumber daya manusia dalam perusahaan. Hal ini berbeda dari pengungkapan MC dan PS yang lebih kearah perekrutan serta tingkat motivasi para karyawan yang diukur melalui tingkat turnover serta pengungkapan motivasi terkait nilai-nilai luhur dalam budaya organisasinya. Berarti, investor memiliki pandangan bahwa informasi QC lebih relevan digunakan dalam memprediksi kemampuan perusahaan dalam jangka panjang dibandingkan MC dan PS. Informasi mengenai pelatihan dan juga CSR perusahaan (lebih sering dalam pengembangan SDM masyarakat) adalah wajib diungkapkan oleh setiap Perseroan Terbatas. Oleh karena itu jumlah pengungkapan informasi terkait hal ini lebih tinggi dibanding pengungkapan informasi lainnya.

NIS dan EQPS yang merupakan variabel kontrol dalam kedua model regresi memiliki pengaruh yang signifikan terhadap harga saham. Hal ini mengindikasikan bahwa keputusan investor dalam melakukan transaksi jual dan beli sangat dipengaruhi oleh informasi laba bersih per lembar saham (NIS) dan nilai buku ekuitas perusahaan per lembar (EQPS).

\section{PENUTUP \\ Kesimpulan}

Penelitian ini bertujuan untuk mengetahui apakah pengungkapan informasi mengenai human capital oleh perusahaan memiliki relevansi nilai terhadap harga perusahaan. Penelitian ini menggunakan unit of analysis keyword untuk menentukan jumlah pengungkapan mengenai human capital yang dilakukan sebuah perusahaan. Berdasarkan hasil penelitian yang telah dilakukan, dapat disimpulkan bahwa pengungkapan informasi mengenai human 
capital ternyata memberikan pengaruh yang positif dan signifikan terhadap share price. Hal ini menunjukkan semakin tinggi perusahaan dalam mengungkapkan informasi mengenai human capital, dapat meningkatkan harga saham yang dimilikinya. Selain itu, jenis pengungkapan informasi human capital terkait qualification dan competence memiliki pengaruh yang signifikan terhadap harga saham. Kompetensi dianggap sebagai sumber daya penting yang mampu mengarahkan suatu individu ataupun organisasi kearah kesuksesan jangka panjang.

\section{Keterbatasan dan rekomendasi untuk penelitian selanjutnya}

Penelitian ini memiliki keterbatasan yang diharapkan bisa menjadi pengembangan untuk penelitian berikutnya. Dalam penelitian ini, analisis pengungkapan human capital hanya menggunakan unit of analysis keywords, yaitu dengan mencari jumlah kata dalam laporan tahunan perusahaan yang sesuai dengan keyword yang dimaksud. Penelitian berikutnya dapat mempertimbangkan kedalaman makna konteks kualitatif pengungkapan informasi human capital.

Obyek yang digunakan dalam penelitian ini adalah terbatas pada perusahaan yang termasuk dalam kelompok high IC intensive industries (berdasarkan pengelompokkan dari Frier dan Williams, 2003) atau perusahaan yang termasuk dalam kelompok industri yang dianggap memiliki ketergantungan tinggi terhadap intellectual capital. Penelitian selanjutnya bisa membandingkan antara hasil yang diperoleh pada kelompok high IC intentive industries dengan kelompok low IC intensive industries.

\section{DAFTAR PUSTAKA}

Abdolmohammadi, M.J. 2005. Intellectual Capital Disclosures and Market Capitalization. Journal of Intellectual Capital, Vol. 6 (3): 397-416.

Abhayawansa, S. dan Guthrie, J. 2012. Intellectual Capital Information and Stock Recommendations: Impression Management? Journal of Intellectual Capital, Vol.13 (3): 398-415.

Barro, R.J. 2001. Human Capital and Economic Growth. American Economic Review, Vol.91 (2): 12-17.

Blaug, M. 1976. The Empirical Status of Human Capital Theory: A Slightly Jaundiced Survey. Journal of Economic Literature, Vol. 14 (3): 827-855.
Dewan Perwakilan Rakyat Republik Indonesia. 2007. Undang-Undang No. 40 Tahun 2007 tentang Perseroan Terbatas. Jakarta.

Dewan Standar Akuntansi Keuangan. 2015. Standar Akuntansi Keuangan (SAK). IAI: Jakarta.

Edvinsson, L. dan Malone, M.S. 1997. Intellectual Capital: Realizing Your Company's True Value by Finding its Hidden Roots, Harper Business NY.

Feltham dan Ohlson, J. 1995. Earnings, Book Value and Dividends in Security Valuation. Contemporary Accounting Reasearch, Vol. 11 (2): 661-687.

Firer, S.S., itchell Williams. 2003. Intellectual Capital an Traditional Measures of Corporate Performance. Journal of Intellectual Capital Vol.4 (3): 348-360.

Gamerschlag, Ramin. 2013. Value Relevanceof Human Capital Information. Journal of Intellectual Capital Vol.14 (2): 325-345.

Lev, B. dan Zarowin, P. 1999. The Boundaries of Financial Reporting and How to Extend Them. Journal of Accounting Research, Vol.37 (2): 353-385.

Lijili, K dan Zeghal, D. 2006. Labor Cost Voluntary Disclosures and Firm Equity Values: Is Human Capital Information Value Relevant?. Journal of International Accounting, Auditing and Taxation, Vol. 14: 121-138.

Petty, R. dan Ricceri, F. 2006. The Voluntary Reporting of Intellectual Capital: Comparing Evidence from Hong Kong and Australia. Journal of Intellectual Capital, Vol. 7 (2): 254-271.

PricewaterhouseCoopers. 2014. A New Vision of Growth: Key Trends in Human Capital $2014 . \quad w w w . p w c . c o m / h u m a n c a p i t a l$. [diunduh tanggal 12 Juni 2015].

Ross, G., Pike,S., dan Fernstrom, L. 2005. Managing Intellectual Capital in Practice, Butterworth Heinemann.

Spender J.C. dan Grant, R.M. 1996. Knowledge and the firm: overview. Strategic Management Journal, Vol.17: 5-9.

Stewart, T.A. 1997. Your Company's Most Valuable Asset: Intellectual Capital. Fortune.

Sullivan, P.H., 2000. Value Driven Intellectual Capital: How to Convert Intangible Corporate Assets into Market Value. New York: Wiley. 
Uyar, A dan Kilic, M. 2012. Value relevance of voluntary disclosure: evidence of voluntary disclosure: evidence from Turkish firms. Journal of Intellectual Capital, Vol. 13 (3): 363-376.

Wyatt, A. 2008. What financial and non-financial information on intangibles is value relevant?
A review of the evidence. Accounting and Business Research, Vol. 38 (3): 217-256.

Zeghal, Daniel dan Maaloul. 2010. Analysing Value Added as an Indicator of Intellectual Capital and Its Consequences on Company Performance. Journal of Intellectual Capital Vol.11 No.1, pp 39-60.

LAMPIRAN

Kategori Pengungkapan Informasi Human Capital

\begin{tabular}{|c|c|}
\hline Category & Keyword \\
\hline \multirow{13}{*}{ Qualification/ competence (13) } & Brain Power \\
\hline & Competence \\
\hline & Competencies \\
\hline & Education \\
\hline & Expertise \\
\hline & Intangible skills \\
\hline & Intelligence \\
\hline & Know-how \\
\hline & Knowledge \\
\hline & Learning \\
\hline & Qualification \\
\hline & Specialist \\
\hline & Training \\
\hline \multirow[t]{8}{*}{ Motivation/ commitment (8) } & Absence \\
\hline & Career \\
\hline & Employee retention \\
\hline & Employee satisfaction \\
\hline & Employee turnover \\
\hline & Enterpreneurial spirit \\
\hline & Motivation \\
\hline & Staff turnover \\
\hline \multirow[t]{6}{*}{ Personnel (6) } & Diversity \\
\hline & Empowerment \\
\hline & Human resource \\
\hline & Personnel \\
\hline & Recruiting \\
\hline & Recruitment \\
\hline
\end{tabular}

Sumber: Gamerschlag, 2013 